\title{
The Mercy of God as the Foundation of Charity of the Church
}

\author{
WIESEAW PRZYGODA* \\ https://doi.org/10.31823/d.27.4.4 \\ UDC: $27-144.82-46$ • Original Scientific Paper \\ Received: 18 September 2018 • Accepted: 2 December 2019
}

Summary: Charity diaconia of the Church is not an accidental involvement but belongs to its fundamental missions. This thesis can be supported in many ways. The author of this article finds the source of the obligation of Christians and the whole Church community to charity service in the nature of God. For Christians God is Love (1 John 4, 8.16). Even though some other names can be found, (Jahwe, Elohim, Adonai), his principal name that encapsulates all other ones is Love. Simultaneously, God which is Love showed his merciful nature (misericordiae vultus) in the course of salvation. He did it in a historical, visible and optimal way through his Son, Jesus Christ through the embodied God's Son, Jesus Christ, who loved the mankind so much that he sacrificed his life for us, being tortured and killed at

* Wiesław Przygoda, Prof., Dr. habil., The John Paul II Catholic University of Lublin / Poland, Al. Racławickie 14, 20-950 Lublin, Poland, przygoda@kul.pl the cross. This selfless love laid the foundations for the Church, which, in essence, is a community of loving human and God's beings. Those who do not love, even though they joined the Church through baptism, technically speaking, do not belong to the Church since love is a real not a formal sign of belonging to Christ's disciples (cf. John 13, 35). Therefore, charitable activity is a significant dimension of the Church's mission as it is through charity that the Church shows the merciful nature of its Saviour. A question that needs to be addressed may be expressed as follows: in what way the image of God, who is love, implies an involvement in charity of an individual and the Church? An answer may be found in the Bible, writings of the Church Fathers of and the documents of Magisterium Ecclesiae and especially the teachings of Pope Benedict XVI and Pope Francis.

Keywords: God, God's mercy, Christian mercy, diaconia, mission of the Church. 
For Christians, God is Love ( 1 John 4, 8.16). Even though some other names can be found, (Jahwe, Elohim, Adonai), his principal name that encapsulates all other ones is Love. God revealed his merciful nature (misericordiae vultus) in the course of redeeming us from our sins. He did it in a historic, visible and optimal way through the embodied God's Son, Jesus Christ, who loved the mankind so much that he sacrificed his life for us, being tortured and killed at the cross. This selfless love laid the foundations for the Church, which, in essence, is a community of loving human beings and God's beings. Those who do not love, even though they joined the Church through baptism, technically speaking, do not belong to the Church since love is a real not a formal sign of belonging to Christ's disciples (John 13, 35). Therefore, charitable activity is a significant dimension of the Church's mission as it is through charity that the Church shows the merciful nature of its Saviour. A question that needs to be addressed may be expressed as follows: in what way the image of God, who is love, implies an involvement in charity of an individual and the Church? An answer may be found in the Bible, writings of the Church Fathers of and the documents of Magisterium Ecclesiae and especially the teachings of Pope Benedict XVI and Pope Francis.

\section{God full of love in his essence}

Love can be truly and fully realized only in God. According to H. Urs von Balthasar, we can understand what love is merely through finding God's love in Christ. It is during such a meeting, if it ever happens, that an individual, sinner and egoist, realizes that he/she is devoid of true love. Bearing this in mind, we need to consider the issue of how sinners, despite their vices, may accept God's gift of love and find their place in the relation of loving other people. The Swiss theologian claims that the man $>$ gets to know two things simultaneously: limitations of the act of creation and its sinful numbness $\ll .{ }^{1}$ Obviously, due to our origin (being created in the image and likeness of God), we are equipped with a »pre-understanding « of love, its intuitive feeling. Otherwise, we would not be able to interpret the sign of love in Jesus Christ, through whom love was expressed in a bodily and human form. Hence, a question is raised: how can the revelation of God's love reach the sinful human mind and heart? According to $\mathrm{H}$. Urs von Balthasar, it requires from the man $\gg$ to reform not only his heart, which must confess that it never loved before, but also to reform the mind, which must learn what love is $\ll^{2}{ }^{2}$

Where else can we learn what love is if not through the teachings of John the Evangelist, who, inspired by the Holy Spirit, announced to the world that $\gg$ God is

\footnotetext{
${ }^{1}$ Hans Urs von Balthasar, Wiarygodna jest tylko miłość, (Kraków: Wydawnictwo WAM, 1997), p. 51.

${ }^{2}$ Ibid.
} 
love $\ll$ ? The beloved disciple of Jesus Christ, who experienced the feelings of closeness with his Master, presents the Holy Trinity as a mystery of interpersonal love. ${ }^{3}$ The Holy Trinity is a mutual love between God's beings, a community of loving people, the Existence and life, the truth and unity in God which equal love. God is the ultimate and ideal being. ${ }^{4}$

God, the Father, devotes himself fully to the Son, loves Him infinitely because the Son is His ideal reflection. The Son requites the love and is fully devoted to the Father. This loving relationship is confirmed by Jesus' words: $\gg$ And he that sent me is with me: the Father has not left me alone; for I do always those things that please him « (John 8, 29). The excess of love between the Father and the Son resulted in the Holy Spirit, which is love personified and completion of the Holy Trinity. The Holy Spirit binds the love between the Father and the Son, from whom it stems. ${ }^{5}$ Hence God is a community of love and life between the Father, the Son and the Holy Spirit.

According to Saint Augustine ( +430$)$, the Holy Trinity comprises the Loving (the Father), the Loved (God's Son) and Love personified (the Holy Spirit). ${ }^{6}$ Love, in its essence, is a communion and can only be fulfilled through giving to the others. The Father, understood as a spontaneous and initial love, is the principle of giving to the others. The Son, understood as answering to the Father's initiative, is an ideal of requited love. The Holy Spirit, understood as a love needed to fulfill the previous one, is a personification of love. ${ }^{7}$ In God we can find creative and fruitful Love (the Father), responsive and requited Love (God's Son) and affirmative Love (the Holy Spirit). ${ }^{8}$

Richard of Saint Victor $(+1175)$, taking inspiration from Saint Augustine, claimed that the highest place in our vision of values should be attributed to God. This place is love and God realizes it completely. Love requires multiple subjects. If God were only one person, He would be able to love only himself and other beings. This would not be the finest love as one cannot love fully these who are not fully worth

${ }^{3}$ Czesław S. Bartnik, Dogmatyka katolicka, vol. 1, (Lublin: Redakcja Wydawnictw KUL, 2000), p. 178.

${ }^{4}$ Jean Daniélou, Trójca Święta i tajemnica egzystencji, (Kraków: Znak, 1994), p. 45.

${ }^{5}$ Yves Congar, Wierzęw Ducha Świętego, vol. 2, (Warszawa: Wydawnictwo Księży Marianów, 1995), p. 28.

${ }^{6}$ Saint Augustine, De Trinitate, VIII. 14. PL 42. 960.

${ }^{7}$ Saint Gregory the Great, Richard of Saint Victor, William of Auxerre, Saint Bonaventure, and Saint John Paul II, H. U. von Balthasar, J. Gallo, B. Forte, J. Werbick, inspired by Saint Augustine, develop the agape-theological-communion model of the Holy Trinity.

${ }^{8}$ Bartnik, op. cit., p. 93. 
love. ${ }^{9}$ Therefore we can find one love in God but three loving persons. In God we can find love which is selfless and given completely (the Father); love which is received and given (the Son) and love which is only received and owed (the Holy Spirit). ${ }^{10}$ Each divine person is equally the supreme love yet of a different source which is reflected by their way of being. ${ }^{11}$

Saint Bonaventure ( +1274$)$, also inspired by Saint Augustine, showed that mutual love is more refine than loving oneself, which equals libido. ${ }^{12}$ God is the supreme Goodness because goodness is spread through the Word and the Spirit. One cannot imagine goodness being spread in time and space onto the beings without the eternal Goodness being spread in God's nature. That is why in God we can find mutual love between the Father and the Son and love given to the Holy Spirit. According to Saint Bonaventure, love's perfection is seen when it is reciprocated. Only reciprocated love has a unifying power. The Holy Spirit does not come from the Father or the Son loving themselves but loving each other, hence the third person of the Holy Trinity becomes the junction of their love. ${ }^{13}$ In consequence, the Holy Trinity can be seen as a communion between persons of the ultimate good, loving, equally significant, eternal, coexisting, cooperating and maximally open to serve others.

The truth of the trinitarian life fills the existence of people with meaning as it shows a perspective of development which goes beyond human imagination. The ultimate goal of the human trinitophany is offering divine love to human beings. From the perspective of history of salvation it is the task of God's Son and then the Holy Spirit. In the archpriest's prayer Jesus asks the Father for the unity of the faithful in the world and within the Trinity, just like the Father, the Son and the Holy Spirit are united (John 17,21-22). The Holy Spirit is the sign of criterion of the trinitarian love. Therefore the personal union between the Father and the Son is fulfilled in the Holy Spirit, who realizes the personal community in the Church. ${ }^{14}$

\footnotetext{
${ }_{9}^{9}$ Richard of Saint Victor, De Trinitate, III. 2, SChr 63, p. 169.

${ }^{10}$ Ibid., V. 16-19, pp. 344-356.

${ }^{11}$ Richard of Saint Victor is regarded as the father of personalism. He attributed love with a personal character, treating it as a form of friendship, which assumes an interpersonal relationship. He put forward a new definition of a person: $\gg$ an autonomous being, created in accordance to a certain way of reasonable existence which differs from all the others because of a non-transsmissable feature «. Richard of Saint Victor, De Trinitate, IV. 24, SChr 63, p. 285; see: Congar, op. cit., vol. 3, p. 128-133.

${ }^{12}$ Saint Bonaventure, I Sententia, d. 10 a. 1 q. 1, in: Opera. Quaracchi 1924, vol. 1, p. 195.

${ }^{13}$ Saint Bonaventure, I Sententia, d. 10 a. 1 q. 3 p. 199; d. 10 a. 2 q. 2 p. 202; see. Congar, op. cit., vol. 3, p. 138.

${ }^{14}$ This was confirmed by Jesus: »And I will ask the Father, and he will give you another advocate to help you and be with you forever, the Spirit of truth. [...] But you know him, for he lives with you and will be in you. $\ll$ (John 14,16-17.20).
} 


\section{God, full of mercy in His actions}

God's love towards the man is unreasonable and irrevocable. Yet the man broke the ties of this relationship and deliberately went away from God. The story of this departure is known as the original sin. Yet God did not leave the man in a hopeless place but showed the power of his love, which in the context of the sin took the form of merciful love. Pope Francis in his papal bull Misericordiae Vultus stressed that God's mercy has been with us since the dawn of our times. »Once Adam and Eve sinned, God did not want to leave the mankind on their own, subject to the evil [...] God answers to sins with a wealth of forgiveness. Mercy will always be greater than any sin and God's love will not be limited $\ll .{ }^{15}$ It is worth noting that the first spouses and the first parents experienced the terrible consequences of their sin, yet were still under the protective wings of merciful God. The consequences of the sin were not lifted, on the contrary, they concerned the whole humankind yet with an instant hope for salvation and escape from the tragic consequences. Adam and Eve became the first addressees of the proto-Gospel pointing to the future victory over the sin and its consequences. This victory will be achieved owing to a mysterious woman (cf. Genesis 3,15). This woman is Mary, Jesus' Mother, and in the context of the John's Gospel it is also the Church, being the sign and tool of merciful God.

How does merciful God act in the face of Adam and Eve's betrayal? »For God so loved the world that he gave his one and only Son $\ll($ John 3,16) and $\gg$ But when the right time came, God sent his Son, born of a woman « (Galatians 4,4). God's Son became a man, which is described by John the Evangelist by means of a theological formula: $\gg$ The Word became flesh and made his dwelling among us «. The concept of $\gg$ flesh « (Gr. sarx) covers the whole man and his frailties. The expression used by Saint John means that God's Son permeated the human world, deep down to the roots of what is essentially human ${ }^{16}$. The embodied God became so similar to humans so that he could sympathize with human weaknesses and he $\gg$ experienced it all-all but the $\sin \ll$ (Hebrews 4,15). Saint Paul points to Jesus' humbleness or even vulnerability (cf. Philippian 2,6-11). Jesus humbles himself and takes the form of a slave (Gr. doulos) since he wants to enrich people through poverty ( 2 Corinthians $8,9)$.

God's Son purified the distorted image of the Father that was formed throughout centuries in the human imagination. In the ancient cultures we can find the testimony of trusting God in Heaven. However, as a result of the centuries-old cultural evolution, religious attention was taken off God and turned towards more

\footnotetext{
${ }^{15}$ Francis, Bull Misericordie Vultus, 11.04.2015, 3 [abbreviated: MV].

${ }^{16}$ Walter Kasper, Jezus Chrystus, (Warszawa: Pax, 1983), pp. 200-201.
} 
foregrounded powers and elements ${ }^{17}$. The ancient Greeks dubbed Zeus $\gg$ the Father « yet it did not mean anyone trustworthy. It was rather a reflection of God's ambivalent stance towards people and the human fear of transcendent reality. Zeus' fatherhood was not an idealized reflection of the earthly fathers, sometimes nice, friendly, sometimes side-taking, unpredictable, egoistic and fearsome. Only from the perspective of the embodied God's Son one can learn who God really is. $\gg$ Who saw me saw the Father « (John 14,9). Not only words and deed $s^{18}$ but God's son, Jesus Christ, is a reflection of God the Father.

What is God the Father revealed through Jesus Christ? He is more like a father than a judge. God did not want to judge the man before he himself became a man. $\gg$ Moreover, the Father judges no one, but has entrusted all judgment to the Son, that all may honor the Son just as they honor the Father (John 5,22-23). God's mercy is manifested through not judging the man, even though as the Creator he was entitled to do so, until he experienced the earthly fate through his Son. The Human Son, as Jesus Christ called himself, humbled himself towards the disadvantaged ones, the rejected ones, the betrayed ones, the spat upon ones, those with no dignity, the beaten ones and murdered. When he was praying on the cross with the words of Psalm 22: »My God, my God, why have you forsaken me? « (Matthew 27,46), he became close to those who rejected God and became atheists. There is hope for them too since God does not reject anyone in advance. Jesus Christ, even though was granted the right to judge people, he does not exercise this right but shows the merciful virtue of his Father (misericordiae vultus). He confirmed it solemnly in the following words: »Whoever hears my word and believes him who sent me has eternal life. He does not come into judgment, but has passed from death to life $\ll$. What we call $\gg$ judgment $\ll$ is a natural consequence of accepting or rejecting a merciful offer by God. $\gg$ Do not be amazed at this, for a time is coming when all who are in their graves will hear his voice and come out-those who have done what is good will rise to live, and those who have done what is evil will rise to be condemned « (John 5,28-29). That is why it is important for Christians to recognize the merciful Father in the face of His Son, who is the only source of the

\footnotetext{
${ }^{17}$ Josef Ratzinger, Bóg Jezusa Chrystusa, (Kraków: Znak, 1995), p. 38.

${ }^{18}$ The image of God, the Father, plays an important role in the teachings of Jesus Christ. It does not, however, provide any doctrinal statements yet reveals His close bond with God, whom he calls $\gg$ the Father «. In many parables offering an image of family life, Jesus testifies to the love and good of Heavenly Father towards his children. »If you, then, though you are evil, know how to give good gifts to your children, how much more will your Father in heaven give good gifts to those who ask

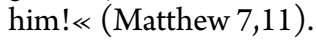


sinful man in the $21^{\text {st }}$ century. Mercy, as it is stressed by Archbishop Grzegorz Ryś, is the kerygma of Christianity for the third millennium. ${ }^{19}$

What is mercy, which finds its source in God and should be reflected in interpersonal relations since the man was created in the image of God? According to Pope Francis, the concept of mercy encapsulates a synthesis of the mystery of the Christian faith. »Mercy: the word reveals the very mystery of the Most Holy Trinity. Mercy: the ultimate and supreme act by which God comes to meet us. [...]. Mercy: the bridge that connects God and man, opening our hearts to the hope of being loved forever despite our sinfulness « (MV 2). Mercy is a love that is faithful despite difficulties, love that never gives up even in the case of the unfaithful man. It is a tender love, full of emotion, just like the love of the best mother. Mercy is not limited to the element destroyed by sin but leads towards a new creation, mends what is damaged or broken. Mercy is God's subtle and delicate intervention into the life of the man, lost and plunged intro trouble. The Latin etymology of the word, misericordia is all about the heart (cor) being given to the man in need (miser). Mercy is active compassion that does not leave the man in any material, psychological, social or spiritual need. God is merciful and wants us to follow his example and build our relationships on the basis of mercy. »Be kind and compassionate to one another, forgiving each other, just as in Christ God forgave you « (Ephesians 4,32).

The unparalleled example of active mercy for Christians is Jesus Christ. ${ }^{20}$ As a man he communicated with people in an earthly way, verbally and non-verbally. As Pope Francis maintains, mercy permeated both means of communication. Mercy was shown and palpable in whole life of Jesus Christ, his words, deeds and attitudes. As the Pope stresses: »The signs he works, especially in favour of sinners, the poor, the marginalized, the sick, and the suffering, are all meant to teach mercy. Everything in him speaks of mercy. Nothing in him is devoid of compassion $\ll$ (MV 8).

\section{The Church as a community of merciful love}

Jesus fulfilled his mission of Revelation of his Father's merciful virtue (John 13,1), when he died at the cross for the whole human race. As he noted himself $\gg$ Greater love has no one than this: to lay down one's life for one's friends « (John 15,13). When Jesus died, stabbed by a Roman soldier in the side, the Church began its mission accompanied by the force of the Holy Spirit. The era of the Church began which is supposed to spread the word, promote, celebrate and be merciful to the

${ }^{19}$ Grzegorz Ryś, Skandal miłosierdzia, (Kraków: Wydawnictwo WAM, 2015), p. 165.

${ }^{20}$ See: Wiesław Przygoda, 》Uwierzyć miłości, by stać się świadkiem miłości,« in Perspektywy wiary, ed. Marek Jagodziński, (Radom: Wydawnictwo Diecezji Radomskiej Ave, 2015), p. 69-91. 
others. Therefore, the Church is the venue of permanent revelation of God's merciful virtue (misericordiae vultus) to all the next generations till the end of the world.

According to Pope Francis, the Church is not a bureaucratic organization but a love story. $\gg$ We, the people of the Church, are in the middle of a love story. Everyone is a link in this chain of love. If we do not understand this, we have understood nothing of what the Church is. It is a love story $\ll{ }^{21}$ The Church is permanently born in the heart of God, who is love ( $1 \mathrm{John} 4,8$ ). $\gg$ For God so loved the world that he gave his one and only Son, that whoever believes in him shall not perish but have eternal life « (John 3,16). The Son loving his Father endlessly loves people in the same way and let himself be hung on the cross only to resurrect on the third day so that they may have life, and have it to the full (cf. John 10,10). This is the genesis of the God-human love that is preserved in the Church and has been present in the Eucharist for more than 20 centuries (1 Corinthians 13,8) and shapes the heart to the image of the Sacred Heart of Jesus, the burning centerpiece of love.

The Church has its source in the lives of God's people and in serving people. God in the Holy Trinity, out of surplus of love, wanted to incorporate people and angels in the circulatory system of love. God's love is an absolute beginning and reason for interpersonal love. The Father, being infinitely fertile, offers a life of love through his Son and in his Son. Therefore, the life of the Church is in fact the life of Jesus Christ, who allows his followers to participate in his filial duties. The life of the Church is realized through the Holy Spirit, who acts in people internally, gives them love and dignity worthy of God's children. ${ }^{22}$

The Second Vatican Council shows that $\gg$ the Church is in Christ like a sacrament or as a sign and instrument both of a very closely knit union with God and of the unity of the whole human race « (Lumen Gentium, 1). The Church is first and foremost a sign of the Father's and Son's love in the Holy Spirit. The Church is also a tool allowing people to take part in God's community of love. In this context, the ability to love becomes the primary condition of entering the community and living in it. Thanks to love we can talk about some similarity that happens between the oneness of God's children and the oneness of the persons in the Holy Trinity (cf. John 17,21-22). Those who love God shall love people, who were first loved by God. This is the source of loving the other, which plays a pivotal role in building the community of the Church (cf. Ephesians 4,16).

\footnotetext{
${ }^{21}$ Francis, »W historii miłości. Homilia podczas Mszy św. w Domu św. Marty,《 23.04.2013, in Osservatore Romano (Polish Edition) 34 (2013) no. 6, p. 28-29.

${ }^{22}$ Daniélou, op. cit., p. 49-50.
} 
The loving nature of the Church should be manifested in the world by its members. Only the Church offering an active and serving love may be reliable and trust-worthy to the world. It requires from the people of the Church to care for spiritual renewal, development of love in a dialogue with God's people and with each other. Love is boundless, we can always love more, stronger, wiser, more courageously, with no interest. Only the Church understood in a trinitarian, personal and dynamic way may cope with the task of multiplying love in the world, and become a tool of historic and anthropological $\gg$ perichoresis of love $\ll{ }^{23}$

The Church built at God's initiative is appointed to mediate in passing God's love and life to people. Through spreading the word and offering sacraments, the Church bears and rears its followers preparing them to live a life of love. The end of this process is leading them towards the eternal glory of God. No one is excluded from God's plan of salvation and the Church is a sign and a tool of introducing people into the trinitarian existence of the Father's, the Son's and the Holy Spirit's love.

\section{The obligation of the Church to serve others}

Nowadays the Church is more and more aware of its task to serve others. It is truly the essence of the mission of the Church. Being faithful to Christ-Servant and threats to human dignity in the contemporary world call for realization of the model of the serving Church. ${ }^{24}$ It must be a process which does not exclude any Christian followers. Those who exclude themselves from the process cease to be a living organism in the Church. Is this belief shared by the majority of the Church members? The answer can be found in the everyday lives of today's followers of Jesus Christ.

It must be admitted that the theological discourse did not always mention the serving character of the Church, which is supposed to be a community of loving and support-giving people. After the Second Vatican Council the issue was raised by Richard Völkl, ${ }^{25}$ the head of the Institute of Charity Studies at the University of Freiburg. However, the post-council documents of Magisterium Ecclesiae did not offer any clear explanation of charity service in the missionary activity of the Church. Klaus Baumann noticed that among the bulk of documents created during John Paul II's pontiff, none of them mentioned directly the issue of charitable work of

\footnotetext{
${ }^{23}$ Krzysztof C. Kaucha, Miłość za miłość. Wiarygodność chrześcijaństwa wedtug Battisty Mondina, (Lublin: Redakcja Wydawnictw KUL, 2000), p. 261.

${ }^{24}$ See: Wiesław Przygoda, Postuga charytatywna Kościoła w Polsce, (Lublin: Wydawnictwo KUL, 2004), pp. 92-106.

${ }^{25}$ See: Richard Völkl, »Ecclesia caritatis, « in Caritas 1965, vol. 66, pp. 113-125; idem, »Kirche und 'caritas' nach dem Zweiten Vatikanischen Konzils, « in Caritas 1966, vol. 67, pp. 73-96; 123-145; idem, Dienende Kirche, Kirche der Liebe, (Freiburg: Seelsorge-Verlag, 1969).
} 
the Church. The Pope called people to love their neighbours rather than to engage themselves in active and professional charity work. It was not until Benedict XVI became the Pope that he promoted the effective and well-organized charity work in his first encyclical letter. ${ }^{26}$ Baumann quotes the Pope just before he announced his first encyclical letter, which can be summarized as follows: $\gg$ In the same way in which the human proclamation of the Gospel, the word of faith, parallels the divine Logos, the agape of the Church, her charitable work, must also parallel the divine Agape, which is God $\ll .{ }^{27}$

In the encyclical letter Deus Caritas Est, Pope Benedict XVI confirmed that $\gg$ the internal nature of the Church is expressed in a triadic task: spreading the word (kerygma-martyria), performing sacraments (leiturgia), and the service of charity (diaconia). These are interconnected tasks that cannot be separated $\ll{ }^{28}$ The Pope states that $\gg$ the Church cannot neglect the service of charity any more than she can neglect the Sacraments and the Word « (DCE 22). The teachings of John Paul II was of a similar character, with the Pope stating that the Church should become »home open to everyone and ready to serve everyone $\ll .{ }^{29}$ According to Benedict $\mathrm{XVI}$, the Church is God's family in the world, where $\gg$ no one ought to go without the necessities of life $\ll$ (DCE 25).

The charitable function of the Church should not be limited to secular philanthropy or any other form of social support. It is about sharing the gift of God's love. That is why caritas in the Church may not be conceptualized from the horizontal perspective of the man's life. The service of charity should be employed even in the case of an unconscious desire for the truth, life to the full and salvation, which are delivered by Jesus Christ. According to Cardinal R. Sarah, »secularization of works of mercy in the final analysis is harmful to the man and his deep desire which is God $\ll .^{30}$ Therefore it is important to constantly remind us about the spiritual dimension of the service of charity in the Church and the need to cater for the spiritual life of the volunteers. ${ }^{31}$

\footnotetext{
${ }^{26}$ Klaus Baumann, »Focusing on the Basics in the Service of Renewal. The Scope and Effects of the Encyclical 'Deus caritas est' more than ten Years after its Publication, « in Roczniki Teologiczne 2017, vol. 64(6), pp. 9-10.

${ }^{27}$ Cf. Pontificium Consilium Cor Unum, Acts of the World Conference on Charity, Vatican: New Synod Hall, 23-24 January 2006, (Rome: Ed. Vaticana, 2007), p. 9.

${ }^{28}$ Benedict XVI, Encyclical Deus Caritas Est, 25.12.2005, 25 [abbreviated: DCE].

${ }^{29}$ John Paul II, Apostolic Exhortation Chistifideles Laici, 30.12.1988, 29.

${ }^{30}$ Robert Sarah kard., »Chcemy służyć ubogim, $\ll$ in Caritas 2012, no. 1, p. 8.

${ }^{31}$ Cf. Sekretariat der Deutschen Bischofskonferenz, Berufen zur caritas, 5.3, in Die deutschen Bischöfe, Bd. 91, Bonn 2009, p. 45-50.
} 
The service of charity in the Church find motivation in God yet on the other hand it hopefully looks to the future, guaranteeing a full liberation from pain and granting an eternal communion with God in love, $\gg$ which never fails $\ll$ ( 1 Corinthians 13,8 ). A perspective of faith and hope makes the workers and volunteers of caritas in the Church not only join the social service but also support the spiritual renewal of the community. As Pope Francis notes, charity done in the spirit of the Gospel $\gg$ is always a service full of hope, which looks forward knowing that only through God and resurrected Christ our society can find solid and lasting foundations $\ll^{32}$

According to Cardinal Walter Kasper $\gg$ the Church without caritas and mercy would not be the Church of Jesus Christ $\ll .{ }^{33}$ Nobody can feel exempt from practising merciful love. Pope Francis, referring to the biblical vision of the Church as Christ's body, stresses that each Christian follower must find their place and role in the community, which was given by Christ. »Christ is a mirror in which [they] find their own image fully realized. Through Christ we find ourselves not as individuals but see ourselves as members of the body of Christ, in a relationship with Christ and His followers $\ll .34$

\section{Caring from a Catholic character of charity work}

Pope Benedict XVI, in the preamble of the motu proprio Intima Ecclesiae Natura, reminded the faithful engaged in various forms of charity work about the principle of the encyclical Deus Caritas Est, which states that $\gg$ practical work is not sufficient if it does not go with love to the other, love which is fed by meeting with Christ « (no 34). Introducing this principle to the ecclesial life serves to build a communion in the Church and also raises the expectations for Catholic charity organizations, which cannot limit their activity only to collecting and distributing money but should take care of those in need and $\gg$ perform a pedagogical role in the Christian community, supporting an education of sharing, respect and love, according to Jesus' teachings $\ll{ }^{35}$

The service of charity of the Church, on all levels must overcome the risk of becoming an ordinary center of support (cf. DCE 31). According to P.J. Cordes, being involved in helping others became an integral part of the culture in the Western

\footnotetext{
${ }^{32}$ Francis, Encyclical Lumen fidei, 29.06.2013, no. 57.

${ }^{33}$ Walter Kasper, »Trzeba szerzyć w Kościele kulturę miłosierdzia,« in Osservatore Romano (Polish Edition) 34 (2013) no. 5, p. 54.

${ }^{34}$ Francis, Encyclical Lumen fidei, 22.

${ }^{35}$ Benedict XVI, Motu proprio Intima Ecclesiae Natura, 11.11.2012, Introduction.
} 
world. ${ }^{36}$ Nowadays we deal with a specific free market of charity-support institutions. The Church is not alone, as it used to be starting from the antiquity until the enlightenment era, in helping the poor and the needy. The Church is somehow destined to cooperate with state institutions in helping people to deal with more and more complicated and harsh realities of poverty. ${ }^{37}$ Most of the Western countries implemented the law promoting the development of charity campaigns by economic entities. State and self-government institutions also cooperate with charity organizations within the Church in specific humanitarian enterprises, being in possession of considerable funds, e.g. to overcome drug addictions or homelessness, to support an integral development of children and adolescents from dysfunctional families. New, often undesirable phenomena could be observed in this respect. Economic entities make use of charity to promote themselves, and the governments use their contributions as a form of socio-political lobbying on an international scale.

The Church has no choice but to find its place in this new cultural context of charity work, yet maintaining its specificity and objectives, which not always converges with those of humanitarian organizations. The Church, caring for its identity and realization of its mission, the integral part of which is to help those in need (cf. Lumen Gentium 12, 46; Apostolicam Actuositatem 8, 31), cannot separate itself from other humanitarian institutions because it would not be able to meet the challenges of the modern times without allies from outside. ${ }^{38}$ The Church offers its services to people in the world therefore it cannot be blind to the challenges of this earthly world by focusing only on the heavenly world. The Church should perceive people in many contexts which can lead to their salvation and damnation. Christians should undertake various charity initiatives which counterbalance the destructive tendencies of the man and instead improve conditions of their everyday life. ${ }^{39}$

Currently we are dealing with a situation when charitable entities in the Church, including Caritas, belong to non-governmental organisations, creating the so-called »third sector $\ll$ in democratic countries. ${ }^{40}$ This makes Catholic organisations part-

\footnotetext{
${ }^{36}$ Paul J. Cordes, Niosący pomoc nie spadają z nieba. Caritas i duchowość, (Kielce: Wydawnictwo Jedność, 2009), p. 139.

${ }^{37}$ Ibid, p. 140.

${ }^{38}$ Ibid., p. 141; cf. Paul J. Cordes, »Przymioty ludzkie i duchowe tych, którzy działają w kościelnych organizacjach charytatywnych, « in Nic nie zastąpi miłości, ed. Zbigniew Sobolewski, (Kielce: Wydawnictwo Jedność, 2009), pp. 48-49.

${ }^{39}$ Cordes, Niosacy pomoc nie spadaja z nieba, pp. 142-143.

${ }^{40}$ Cf. Wiesław Przygoda, »Caritas as the Third Sector of Society in Poland, « in Caritas et Veritas 2017, no. 1 pp. 115-124.
} 
ners for the governments together with various other humanitarian organisations, holding various beliefs and having often different outlooks on the world. The context of cultural pluralism requires a great deal of caution when making alliances, especially when the partners of solidarity campaigns are political parties or movements. The Church may not get involved in social activity that aims at coming to power or wielding power. This would be uncalled for since the mission of the Church is to show a redeeming perspective to all the people, not only selected groups of certain political beliefs. Hence the task of charity organisations in the Church is also to keep the memory of the biblical roots of love towards the neighbour and to cultivate a rich heritage of Saint Basil of Caesarea, Saint Martin of Tours, Saint Elizabeth of Thuringia, Saint Vincent de Paul, Saint Albert Chmielowski of Kraków and many other Christian witnesses of love. ${ }^{41}$

Caring for the Catholic character of the institution, form and means of charitable activity imposes certain tasks on priests, especially diocese bishops. In the motu proprio Intima Ecclesiae Natura the Pope reminded us that »apart from following the rules of canon law, charity organisations, [...] are obliged to follow Catholic principles and may not accept commitments that would condition the following of those principles « (art. 1, $\mathbb{S}$ ). The welcome cooperation of charity organisations in the Church with state institutions ${ }^{42}$ supported by Magisterium Ecclesiae may lead to a collision of Catholic ethics with the binding law of a given country. Unfortunately, more and more often, from the perspective of Catholic ethics, we deal with immoral civil law. It concerns mostly the area of protection of human life from birth till natural death, also the area of marital, family life and children education. In some Western countries, the activity of charity institutions in the Church was implemented in the state administration procedures, which was against the principles of Catholic ethics.

The motu proprio Intima Ecclesiae Natura shows that the duty of diocese bishops and priests is to monitor if the faithful are not mislead when it comes to the objectives and motivations of the undertaken charity initiatives. Therefore $>$ they should forbid the promotion of those initiatives through parish or diocese structures that would entail making choices or using methods contrary to the teaching of the Church « $(\operatorname{art} .9, \$ 3)$. Unfortunately, it must be realized that today's charity activity is a tool of propaganda. It is unacceptable to use service of love offered by the Church in order to achieve goals that go contrary to the mission of the Church. Hence $\gg$ a diocese bishop should make sure that subordinate charity organisations

\footnotetext{
${ }^{41}$ See: Paul J. Cordes, »Tuet Gutes allen!«. 21 Thesen zur Caritas-Arbeit, (Paderborn: Bonifatius Verlag, 1999), p. 83-108.

${ }^{42}$ DCE 30; cf. John Paul II, Encyclical Sollicitudo Rei Socialis, 30.12.1987, 32-34.
} 
are not funded by institutions or organisations whose ambitions clash with the teachings of the Church. Similarly, in order not to deprave the faithful, a diocese bishop should prevent charity organisations from collecting money aimed at funding the initiatives that do not go along with the teaching of the Church $\ll$ (art. 10, \$3).

In the apostolic exhortation titled Evangelii Gaudium, Pope Francis repeated after St. John Paul II that $\gg$ without preferential optioning for the poor 'preaching the Gospel, being the first dictate of mercy, may remain misunderstood and be lost in words we are flooded by the media in the contemporary world' $\ll .{ }^{43}$ If the Church wants to be trust-worthy, also in those countries where it form the minority, it is to be so because of its charity and activity which stems from solidarity with those in need ${ }^{44}$. Therefore, Pope Francis believes that the Church may not be exempted from caring for the poor and striving for social justice. $\gg$ Spiritual renewal, living love for thy neighbour and God, caring for peace and justice, evangelical treatment of the poor and poverty is to be expected from everyone $\ll .{ }^{45}$

Mercy can be seen as an ideal of the Christian life and a criterion of the redeeming credibility of the mission of the Church. Mercy is a key word to understand the main message of Revelation, which tells us that God loves us, is responsible for us, wants us to be happy, joyful and peaceful. According to Pope Francis $\gg$ this is the wavelength that Christian merciful love should be tuned to. Sons should love just like the Father does. Since he is merciful, we are also asked to be merciful in the same way« (MV 9).

The world has the right to expect an example of love of service and sacrifice from the Church. The Church as »a sign and a tool « should become a virtue of humbleness, sacrifice and service. In practice, the authority and credibility of the Church is increased most through the testimony of selfless love of its members. Charity service in the life and activity of the Church seems invaluable. That is why it is worth taking care of various works of love, especially in parishes and other communities of the faithful. Only parishes full of love, and through them the Church, may shine fully and regain credibility of their teachings, authenticity in liturgy and community (communio) in their redeeming mission.

\footnotetext{
${ }^{43}$ Francis, Apostolic Exhortation Evangelii Gaudium, 24.11.2013, 199; cf. John Paul II, Apostolic Letter Novo Millennio Ineunte, 6.01.2001, 50.

${ }^{44}$ Francis, Apostolic Exhortation Evangelii Gaudium, 65.

${ }^{45}$ Ibid., 201.
} 


\title{
BOŽJE MILOSRĐE KAO TEMELJ DJELATNE LJUBAVI CRKVE
}

\author{
Wiesław PRZYGODA*
}

Sažetak: Dobrotvorna dijakonija Crkve nije tek slučajna uključenost, već spada u njeno temeljno poslanje. Ova teza može se podržati na više načina. Autor ovoga članka pronalazi izvor obveze kršćana i čitave crkvene zajednice prema dobrotvornom služenju u Božjoj prirodi. Za kršćane Bog je Ljubav (1 Iv 4, 8.16). Iako se mogu naći i neka druga imena (Jahwe, Elohim, Adonai), njegovo glavno ime koje obuhvaća sva druga jest Ljubav. Istodobno, Bog koji je Ljubav pokazao je svoju milosrdno lice (misericordiae vultus) u povijesti spasenja. Učinio je to na povijesni, vidlijiv i optimalan način po svome Sinu, Isusu Kristu, utjelovljenom Božjem Sinu, koji je toliko ljubio čovječanstvo da je za nas žrtvovao svoj život, mučen i ubijen na križu. Ta nesebična ljubav postavila je temelje Crkvi koja je u svojoj biti zajednica ljubavi ljudskih i Božjih bića. Oni koji ne ljube, iako su krštenjem pridruženi Crkvi, tehnički gledano, ne pripadaju Crkvi budući da je ljubav stvarni, a ne formalni znak pripadnosti Kristovim učenicima (usp. Iv, 13, 35). Stoga je karitativni rad značajna dimenzija crkvenog poslanja, jer upravo kroz djelotvornu ljubav Crkva pokazuje milosrdno lice svoga Spasitelja. Pitanje na koje je potrebno odgovoriti može se postaviti na sljedeći način: na koji način slika Božja, koji je ljubav, podrazumijeva uključenost pojedinca i Crkve u dobrotvorni rad? Odgovor se može pronaći u Bibliji, u spisima crkvenih otaca $i$ dokumentima Magisterium Ecclesiae, a posebno u učenju pape Benedikta XVI. i pape Franje.

Ključne riječi: Bog, Božje milosrđe, kršćansko milosrđe, dijakonija, poslanje Crkve.

* prof. dr. sc. Wiesław Przygoda, Katoličko sveučilište Ivana Pavla II. u Lublinu, Al. Racławickie 14, 20-950 Lublin, Poljska, przygoda@kul.pl 